\title{
AN INTERSECTIONAL APPROACH TO INVESTIGATING PERSISTENCE AMONG WOMEN OF COLOR TENURE-TRACK ENGINEERING FACULTY
}

\author{
Ebony O. McGee, ${ }^{1, *}$ Joyce B. Main, ${ }^{2}$ Monica L. Miles, ${ }^{3} \mathcal{E}$ \\ Monica F. Cox
}

${ }^{1}$ Department of Teaching and Learning, Peabody College of Vanderbilt University, PMB Box 230 GPC, 230 Appleton Place, Nashville, Tennessee 37203, USA

${ }^{2}$ School of Engineering Education, Purdue University, 701 West Stadium Ave., West Lafayette, Indiana 47907, USA

${ }^{3}$ Cornell University, New York Sea Grant, 202 Jarvis Hall, Buffalo, New York 14260, USA

${ }^{4}$ Department of Engineering Education, The Ohio State University, $244 \mathrm{~F}$ Hitchcock Hall, 2070 Neil Avenue, Columbus, Ohio 43210-1278, USA

\footnotetext{
*Address all correspondence to: Ebony O. McGee, PhD, Associate Professor of Diversity and STEM Education, Associate Professor of Medicine, Health, and Society, Department of Teaching and Learning, Peabody College of Vanderbilt University, PMB Box 230 GPC, 230 Appleton Place, Nashville, TN 37203; Tel.: +615-343-2596, E-mail: ebony.mcgee@vanderbilt.edu
}

A growing body of literature has examined the underrepresentation of women of color (WOC) in university engineering programs, but its primary focus has been on the experiences of women students of color. Research on WOC in engineering is usually drawn from all of science, technology, engineering, and mathematics, which does little to illuminate the nuanced experiences of WOC within engineering culture. We sought a primary emphasis on persistence and perseverance rather than the typical examinations on mentoring, inventions, work-life balance, or the challenges that WOC face in engineering faculty environments. There are few studies on how and why women of color persist in academia in the face of the intersection of racism and sexism. Using intersectionality as a theoretical framework and inductive qualitative analyses of interviews with 56 women of color who identified as Asian, Black, Latina, and/or multiracial, we analyzed the sources of support for their persistence. Asking which collective factors support WOC in general and which are unique to each of the racial/ gender groups, we identified three major themes-persistence is aided by (1) supportive colleagues internal to the department or institution, (2) supportive colleagues external to the institution, and (3) the intersectional considerations of group-specific nuances shared by Black, Latina, and Asian women engineering faculty members. The implications suggest women of color thrive in departments with supportive faculty, proactive leadership, and a commitment to professional development. We outline specific racial group interventions that can be beneficial for Asian, Black, and Latina engineering faculty.

KEY WORDS: women of color, intersectionality, faculty, higher education, engineering, persistence, Asian faculty, Black faculty, Latina faculty, multicultural faculty 


\section{INTRODUCTION}

Diversification of faculty is a priority for many higher education institutions, but it has been met with little success (Ahmed, 2012; Espinosa, 2011; McGee et al., 2020; Ong et al., 2018). Many diversity initiatives have targeted recruiting and retaining underrepresented populations in STEM, but when it comes to women faculty, there is a lack of specificity in relation to women of color (WOC) (Berry et al., 2014; Espinosa, 2008). While scholars have explored the culture and climate of engineering environments as hostile or unwelcoming for future WOC faculty (e.g., Robinson et al., 2016), less attention has been given to why WOC continue to seek faculty positions and why they remain in the academy. Many reports that focus on improving the number of women faculty in engineering do not specifically focus on women of color or intersectionality, missing out on crucial research that could assist with WOC recruitment and retention (e.g., Main et al., 2020). At the same time, there are few empirical studies that describe WOC faculty in STEM fields (cf., Ong et al., 2011, 2018). Most of these lump WOC as one monolithic group, not delineating the specific challenges of each racial group. As a result, we seek to understand persistence for those WOC who remain in tenured faculty appointments by examining the factors that contribute to their successful retention and their commitment to their roles as faculty members.

This study sheds light on the experiences of WOC engineering faculty who persist in the field despite a host of negative environmental conditions (e.g., hostile and unwelcoming environments) (McGee, 2016; Turner and González, 2011). Administrators, peers, and White women within engineering can use an understanding of WOC persistence to provide an optimal support system that is conscious of raced gendered lives and academic space that WOC must navigate (McGee and Bentley, 2017; Turner and González, 2011). This understanding can best inform intervention efforts, such as professional development for engineering departments, that wish to protect and enhance the experience of WOC faculty members. To that end, our research question is: What are the institutional and noninstitutional factors that lead to persistence in engineering among WOC faculty? We examine this question from an intersectional and antideficit framing focusing on persistence theory to unpack the complexities of multiple complex identity markers that can offer support for persistence even within often hostile and inequitable environments (Espinosa, 2011).

As women of color ourselves, we acknowledge the remarkable resilience and strength WOC exhibit in the face of systemic racism and sexism. As women of color authors, we stand in solidarity with these WOC engineering faculty who have sought to protect their hearts and well-being. Although we seek culturally affirming inclusion where racism and sexism no longer undermine positive outcomes for WOC engineering faculty members, we are also determined to showcase the benefits and contributions of WOC engineering faculty. Women of color deserve attention for their persistence and determination in their mostly White male Eurocentric academic environments. Their persistence, after all, benefits us all. 


\subsection{Demographics of the Engineering Faculty Landscape}

According to the National Center for Education Statistics (NCES), women of color, defined as African American/Black, Hispanic/Latina, Asian/Asian American, Native American, and multiracial women, are vastly underrepresented among full-time faculty at degree-granting institutions (NCES, 2017). For example, Black women constitute $3 \%$ of faculty, Latinas 3\%, Asian/Pacific Islander women 5\%, and Indigenous/Native American women constitute less than $1 \%$ of the faculty. Their male counterparts are also underrepresented among the general faculty populations, Black men (3\%), Latinx (3\%), Asian/Pacific Islander men (6\%), whereas White men $41 \%$ and women $35 \%$ are either representative of the national population or are overrepresented among general faculty populations.

While the racial/ethnic disparities among all faculty of color are alarming, particularly for African Americans, Latinx, and Native Americans, the disparities within engineering fields are even more severe. According to Yoder (2017), women represent only $16.9 \%$ of all engineering tenure-track faculty. Non-Asian people of color represent a relatively small proportion of engineering tenure-track faculty, with Black and Latinx groups holding only $2.3 \%$ and $3.9 \%$ of engineering faculty positions, respectively. Asian and Pacific Islander professors, primarily Asian men, make up 27.9\% of engineering faculty. Comparing data from Yoder (2017) and from the National Research Council (1998) reveals that the percentage of faculty from minoritized populations in engineering has remained stagnant.

\subsection{Women of Color in STEM}

WOC represent a small but growing group of faculty across the United States. In 1993, WOC approximately accounted for $4 \%$ of all full-time instructional faculty in STEM (Aguirre, 2000). Two decades later, WOC comprised 5.1\% of nontenured track and $2.3 \%$ of tenured or tenure-track faculty in the STEM fields (Ginther and Kahn, 2012). Despite their sustained involvement in US institutions, WOC still struggle with the issue of gross numerical underrepresentation in STEM fields.

Scholarship has discussed underrepresentation of WOC in higher education but lacked an extensive investigation of the experiences of belonging to at least two marginalized groups in STEM — women and people of color. Malcolm et al. (1976) and DeJoie (1977) describe the experience of WOC as a "double bind" where WOC are burdened by both racism and sexism within STEM environments, which impedes advancing through the academic ranks (Turner, 2002). Research investigating the discrimination, racialized pressure to succeed at all costs, and isolation experienced by WOC in higher education acknowledges that these issues inadvertently reveal the role of intersectionality, since the intersectional identities of WOC can affect their raced and gendered interactions in White-male-normed STEM environments (Eastman et al., 2019).

WOC in STEM encounter distinct issues in STEM fields in response to their intersectional identities. They experience microaggressions (Ong et al., 2018), alienation, lack

Volume 27, Issue 1, 2021 
of mentoring (Jean-Marie and Brooks, 2011), tokenism (Turner and González, 2011), or "pet-to-threat" syndrome - where WOC are initially praised for their work until they are viewed as a threat in their workplaces (Thomas et al., 2013; Johnson et al., 2017). In tokenism WOC are a numerical minority and often assigned the role of sole representative or spokesperson for their race, gender, or both within their institutional spaces (Turner and González, 2011). For example, WOC are tasked with additional service responsibilities within their departments to have more visible representation of women and/or people of color (McGee and Bentley, 2017). The lack of departmental and institutional support to recruit and retain a diverse faculty is also detrimental to WOC's professional development (Armstrong and Jovanovic, 2015). Scholars have described the conundrum in which WOC often find themselves split between their personal and professional identities in STEM. They feel pressure in committing to the academy, family, or community (Turner and González, 2011; Turner, 2002). They also describe needing to prioritize their academic positions over their families to be successful (DeCuir-Gunby et al., 2009; Sallee et al., 2016; Turner and González, 2011).

These pressures have been well documented for WOC. What is less often studied is STEM WOC persistence in navigating the intersection of racism and sexism. Existing studies on the persistence of WOC in STEM have focused at the undergraduate level and emphasized the low persistence rate of WOC and challenges in STEM (Espinosa, 2011; Ong et al., 2018), but we want to understand how WOC continue to persist in their academia careers. In the current study, we extend the persistence scholarship by fostering a greater understanding of how WOC faculty in engineering fields navigate in institutions in which they may find themselves underrepresented and marginalized.

\subsection{Theoretical Frameworks: Persistence Theory and Intersectionality}

\subsubsection{Persistence Theory}

A small body of literature examines the persistence of WOC in STEM higher education environments, and most of this literature is dominated by the degree completion of women graduate students and their pathways toward academic appointments (Espinosa, 2011; Ong et al., 2018). However, we are often left wondering what happens once they reenter the academy as faculty members. Persistence theory analyzes participants' relationships with their social and academic environments, where more positive relationships and interactions have an impact on increasing persistence (Metz, 2004). The origins of persistence theory are rooted in the field of psychology, as scholars in the field have examined the construct of motivation from a variety of physiological, cognitive, and behavioral approaches. Persistence theory has now been extended to other disciplines, including the field of education (Metz, 2004). Over the past several decades, there has been an abundance of research that examines why students persist in their undergraduate studies (Astin, 1993; Bean and Metzner, 1985; Braxton et al., 2004; Tinto, 1993). Tinto's (1993) model of student persistence has been widely cited by scholars examining student outcomes in the context of higher education. At the core 
of Tinto's (1993) model are the concepts of academic and social integration, which are considered primary predictors of student persistence. Academic integration can be measured in terms of students' grade preference and intellectual development, while social integration is reflected through the interactions with peers and faculty. Students who successfully integrate into the social and academic systems of the institutions will strengthen their commitment to complete their degrees (Tinto, 1993). This model also suggests that entry characteristics (e.g., prior schooling experience), initial and subsequent goals and commitments (e.g., students' aspiration), and institutional experiences (e.g., curricular involvement) can influence students' persistence in completing their studies (Tinto, 1993).

Bean and Metzner (1975) extended the theory of persistence to adult or nontraditional students who are defined as being 25 or older, enrolled part-time, and not residing on campus. Unlike persistence models of traditional students that emphasize the importance of social interactions on campus, the model for adult students underscores social variables from the outside environment, such as family responsibilities, finances, hours of employment, and outside encouragement (Bean and Metzner, 1975). Donaldson and Graham's (1999) model of college outcomes for adults is an effort to comprehensively address the experience of adults on campus. They offer a framework for examining adult learners' persistence by considering the diverse nature of nontraditional students and the impact of environmental factors outside of the institution. The model consists of six components: (1) prior experience; (2) psychosocial and value orientations; (3) the connecting classroom (interaction with faculty and peers); (4) adult cognition; (5) life-world environment; and (6) college outcomes for adults (Donaldson and Graham, 1999).

Studies on the persistence of nontraditional learners in higher education shed light on different factors that influence adult persistence in college and how they actively seek sources of support to persist. This framework could be extended to the study of marginalized faculty (e.g., WOC) within engineering spaces. We are employing persistence theory to investigate why female engineering faculty members of color remain in an environment that may be less supportive or perhaps even hostile. We unearth their creation of valuable relationships with peers, faculty, students, and mentors (Metz, 2004).

\subsubsection{Intersectionality Theory}

Intersectionality theory focuses on the complex, cumulative ways in which multiple forms of discrimination, like racism, sexism, and classism, merge or intersect, especially in the experiences of minoritized individuals or groups - in this case WOC engineering faculty. WOC are operating in White male-dominated environments and cultures and climates. With roots in Black feminism, intersectionality was coined by Crenshaw (1989) and informed by Harding's (1989) institutional, symbolic, and individual dimensions of oppression. Institutional dimensions account for systemic relationships of domination and subordination that are influenced by stereotypical images of race, class, and gendered groups. For example, the negative stereotyped image of the angry Black

Volume 27, Issue 1, 2021 
woman impacts Black women in STEM spaces, where they are considered bossy if they share their knowledge within the group (Harris-Perry, 2011; McGee and Bentley, 2017). Latina women have been misrepresented by stereotypes about their sexuality and presumed promiscuity in hostile STEM environments (McGee, 2016). Asian American women are situated as the best women of color for STEM fields due to the model minority myth (McGee et al., 2016), yet Asian women are evaluated less favorably in STEM when their gender is salient but more affirmatively when their ethnicity is salient (Sinclair et al., 2006).

Institutional dimensions of intersectionality refer to "systemic relationships of domination and subordination" (Collins, 1993, p. 29) in which differing degrees of penalty and privilege are present. For gender, this relates to traits or characteristics that are defined as gendered (e.g., assertiveness is masculine, and passivity is feminine). Finally, individual dimensions of oppression are informed from our institutional and symbolic perspectives. Collins believes that these individual stories can be challenged and can promote larger changes. WOC cannot escape racism because it is everywhere. WOC cannot escape sexism because most people have been taught to believe that men are superior to women.

Turner and González (2011), with an intersectional perspective, address how WOC in STEM have to navigate repeatedly and delicately their personal and professional identities, ultimately sacrificing their personal lives to succeed in their professional fields. Leyva (2016) described how intersectionality attends to multiple dimensions of WOC experience in STEM higher education environments. Those dimensions do not solely focus on the STEM identities and micro experiences of the women but also include the structural constraints that may not be as obvious yet impact their experience (e.g., grossly low numbers of WOC in STEM as a result of structural, inequitable hiring practices and disproportionately lower salaries than their male counterparts).

\section{DATA SOURCES AND METHODS}

This research is guided by an interpretivist paradigm, meaning that we aim to understand participants' subjective experiences, and by a critical paradigm, as this research study was concerned with the participants intersectional commonality and uniqueness. Our aim is to center these persistence narratives of historically and contemporarily marginalized WOC engineering faculty (Decuir-Gunby and Walker-Devose, 2013). This focus is best accomplished in this case with in-depth, semistructured interviews. The interviewers were all four authors on this manuscript; however, McGee and Miles performed the majority of these interviews. We investigated sources of motivation, barriers, and persistence in the context of engineering higher education spaces for WOC across United States postsecondary institutions. Qualitative data were collected from 56 WOC tenure-track faculty through semistructured interviews and focus groups conducted from 2016 to 2019 (see Appendix A for participant characteristics). We sought to understand the sources of support for WOC in STEM higher education that led to persistence. Those sources of support in this study are related to a faculty member's 
pursuit of excellence in research, teaching, and (public) service and are considered as supportive according to participant responses. Then we looked within subgroups to understand the nuances.

Participants included WOC from 40 institutions, including 3 instructors, 19 assistant professors, 14 associate professors, 25 full professors, and 3 participants who solely work in administrative positions. Sixteen participants identified as Asian, 19 participants identified as Black, 11 participants identified as Latina, 6 participants identified as multiracial, 3 participants identified as Middle Eastern, and 2 participants identified as Native American and Indigenous. Faculty were recruited through email solicitations via national conference list serves and engineering department list serves. Participants who responded and agreed to be interviewed in person were interviewed by a member of the research team. Fifty-six interviews were conducted at engineering-related national conferences (e.g., the American Society for Engineering Education), at participants' universities, or over the phone. Twenty-three interviews were conducted in-person and 34 over the telephone. To ensure fidelity across the different groups, all members of the research team who interviewed were trained in interview skills and were given time to review the interview protocol to gain familiarity with the questions in the interview guide. WOC participants received $\$ 50$ for compensation for their time and signed a consent form prior to the interview. Interviews lasted from 45 minutes to 2.5 hours and were transcribed following the interview completion by Rev.Com, a professional transcription service. Participants were asked a series of semistructured questions, some of which include the following:

1. What early influences led you to want to be an engineer and ultimately a professor in engineering?

2. How do you identify racially/ethnically? (Use their answer for next part of the question.) What does it mean to you to be a(n) [insert their answer] woman in your department?

3. Tell me more about the sources of support, both internal and external, to your department that enable you to thrive/persist in your engineering faculty trajectory. (Possible probe: What would you need to thrive in your position if you are not already thriving?)

\subsection{Data Analysis}

The coding team consisted of three faculty members, one postdoctoral researcher, and two graduate students; three of the team members identify as Black, two as Asian, and one as White. The coding team worked alongside the authors of the paper to coconstruct meaning and analyze the data. The team met every other week, and the coding process lasted roughly three months. It involved simultaneous inductive and deductive reasoning, as we were interested in exploring how our theoretical model was supported within this sample of engineering and computing faculty and in emergent themes. We analyzed the transcripts using thematic analysis, a method for identifying, analyzing, organizing, interpreting, and reporting data patterns (Braun and Clarke, 2006; Fereday and Muir-

Volume 27, Issue 1, 2021 
Cochrane, 2006). The transcriptions were analyzed using NVivo 12, a computer-assisted qualitative data analysis platform.

After preliminary analysis, we developed a coding architecture where we shared the codes and potential themes and reconciled any discrepancies. The initial coding architecture contained seven code categories and 56 subcategories. We then recoded, focusing on themes salient to the persistence of the women. This focused coding generated four code categories and 20 subcategories (see Appendix B). The third round of coding, the focus of this paper, was based on the preliminary findings of the second coding round and influenced by the literature on persistence theory (Tinto, 1975) to understand the relationships between WOC and persistence in terms of sources of support both within and outside of their institution the women leverage. We categorized the external support mentioned in interviews and reached final agreement on the coding criteria, which allowed us to generate data on how many women described support within their institution and noninstitutional support (Table 1).

WOC are few, and as such they are at higher risk of being identified by readers. For these reasons, we handled the data from collection to publication with great care and attention to confidentiality. For example, we knew listing the name of the university could lead to compromising confidentiality, so we only list university type in the demographic table (Appendix A). There were also parts of the interviews that some of the interviewees desired to be off the record; we accepted those requests.

As a team, we wanted to understand generalizable supports for the majority of WOC and keep with intersectionality as a theoretical lens. Therefore we needed to see what kinds of institutional or noninstitutional support is specific to certain racial and ethnic groups. We determined specific types of support that were significant for at least $50 \%$ $(\mathrm{n}=28)$ of the women, who described at least one form of support that contributed to their continued persistence in the academy. In Table 2 we have listed types of institutional support and in Table 3 types of noninstitutional support that were revealed in the interviews.

\section{FINDINGS}

We categorized institutional (departmental) or noninstitutional (outside of the department) sources of support for WOC persistence in their engineering departments. The findings are organized in two major sections: (1) support across all racial groups $-70 \%$ of the women described having supportive colleagues as being impactful, and $66 \%$ described the positive effects of outside professional networks and organizations - and (2) intersectional considerations that reveal specific support based on race and ethnic grouping. This section of the analysis identified qualitative nuances within Latina, Black, and Asian subgroups since they were the largest groups sampled. Black women drew on spirituality and other faith-based supports, and Latinas drew on race-based professional organizations. Asian women did not draw on race-based organizations but rather drew from institutional supports like supportive leadership and colleagues. 
TABLE 1: Partial coding architecture

\begin{tabular}{|c|c|}
\hline Code & Description \\
\hline Institutional Support & $\begin{array}{l}\text { Support provided within the institution and/or } \\
\text { department }\end{array}$ \\
\hline Supportive Leadership & $\begin{array}{l}\text { The institution and department leadership (e.g., chairs, } \\
\text { deans, and other administrators) provided emotional, } \\
\text { financial, and career support for WOCs }\end{array}$ \\
\hline Supportive Colleagues & $\begin{array}{l}\text { Faculty members provided emotional, academic, and } \\
\text { teaching (e.g., sharing teaching strategies) support for } \\
\text { WOC }\end{array}$ \\
\hline Internal Mentoring Programs & $\begin{array}{l}\text { The mentorship programs (e.g., faculty mentoring } \\
\text { program) are initiatives by the institution designed to } \\
\text { support WOC }\end{array}$ \\
\hline Department Research Funding & $\begin{array}{l}\text { The institution supports WOCs research through a wide } \\
\text { range of internal research funding (e.g., internal funding } \\
\text { programs) }\end{array}$ \\
\hline Family Support Programs & $\begin{array}{l}\text { The institution has the mechanism (e.g., parental leave) } \\
\text { to help WOC with family responsibilities }\end{array}$ \\
\hline Promotion/Tenure Support & $\begin{array}{l}\text { The institution and department support WOC's tenure } \\
\text { process (e.g., program for proposal writing) }\end{array}$ \\
\hline Noninstitutional Support & $\begin{array}{l}\text { Support provided outside of the institution and/or } \\
\text { department }\end{array}$ \\
\hline Supportive Family and Friends & $\begin{array}{l}\text { WOC receive emotional, development, financial, and } \\
\text { physical support from family (e.g., partner or husband) } \\
\text { or friends }\end{array}$ \\
\hline $\begin{array}{l}\text { Support from Outside Prof. } \\
\text { Networks/Professional Peers }\end{array}$ & $\begin{array}{l}\text { WOC receive emotional, development, and career } \\
\text { support from networking outside of the institution (e.g., } \\
\text { career support from undergraduate advisor) }\end{array}$ \\
\hline Supportive Virtual Spaces & $\begin{array}{l}\text { WOC receive emotional support from virtual spaces } \\
\text { (e.g., Facebook group) }\end{array}$ \\
\hline Physical Fitness as a Support & $\begin{array}{l}\text { Physical fitness provides WOC relief from academic } \\
\text { work (e.g., going to gym) }\end{array}$ \\
\hline Spirituality/Faith-Based & $\begin{array}{l}\text { WOC receive emotional support from spirituality (e.g., } \\
\text { going to church) }\end{array}$ \\
\hline
\end{tabular}

\subsection{Institutional Support across All Racial Groups}

\subsubsection{Supportive Colleagues}

Seventy percent of the women described supportive colleagues within their departments and institutions who enabled them to persist as engineering faculty members. Regard- 
TABLE 2: Institutionally driven sources of support for WOC faculty persistence

\begin{tabular}{|c|c|c|c|c|c|c|}
\hline & $\begin{array}{l}\text { Black } \\
n=19\end{array}$ & $\begin{array}{l}\text { Asian } \\
n=16\end{array}$ & $\begin{array}{l}\text { Latina } \\
n=16\end{array}$ & $\begin{array}{c}\text { Middle } \\
\text { Eastern } \\
n=3\end{array}$ & $\begin{array}{c}\text { Native } \\
\text { American } \\
\mathbf{n}=\mathbf{2}\end{array}$ & $\begin{array}{c}\text { Percentage } \\
\text { of WOC }\end{array}$ \\
\hline $\begin{array}{l}\text { Supportive } \\
\text { Leadership }\end{array}$ & 8 & $* 11$ & 5 & 0 & 2 & $46 \%$ \\
\hline $\begin{array}{l}\text { Supportive } \\
\text { Colleagues }\end{array}$ & $* 15$ & $* 10$ & $* 10$ & 2 & 2 & $* 70 \%$ \\
\hline $\begin{array}{l}\text { Internal } \\
\text { Mentoring } \\
\text { Programs }\end{array}$ & 4 & 3 & 3 & 1 & 0 & $20 \%$ \\
\hline $\begin{array}{l}\text { Department } \\
\text { Research } \\
\text { Funding }\end{array}$ & 0 & 3 & 0 & 1 & 0 & $7 \%$ \\
\hline $\begin{array}{l}\text { Family } \\
\text { Support } \\
\text { Programs }\end{array}$ & 6 & 5 & 2 & 0 & 1 & $25 \%$ \\
\hline $\begin{array}{l}\text { Family/ } \\
\text { Caretaker } \\
\text { Policies }\end{array}$ & $* 13$ & $* 9$ & $* 10$ & 2 & 1 & $* 63 \%$ \\
\hline $\begin{array}{l}\text { Promotion/ } \\
\text { Tenure } \\
\text { Support }\end{array}$ & 0 & 1 & 1 & 0 & 0 & $4 \%$ \\
\hline
\end{tabular}

less of the demographic makeup of the departments, which are primarily White male environments, if the women felt supported, they found this to influence their persistence in the department. For example, Dr. Holly, an associate professor born in China, described her environment as "friendly" in her small private college:

My current environment is very small and it's very friendly. It's a very friendly environment [and] very encouraging. People encourage each other and help each other. If I ask for help, they will help me with whatever. Then they treat me and each other like a friend.

Dr. Holly compares her current institution to her previous one, "I worked in [removed institution name] before; people are kind of competitive with each other ... and here they help each other."

In a different example, Dr. Minerva, a full professor from Puerto Rico, has had positive experiences and enjoyed being a faculty member at her institution. She felt strongly about having supportive colleagues. She even referred to her colleagues as mentors who have helped her in a variety of ways. She added: 
TABLE 3: Noninstitutional sources of support for WOC faculty persistence

\begin{tabular}{|c|c|c|c|c|c|c|}
\hline & $\begin{array}{l}\text { Black } \\
n=19\end{array}$ & $\begin{array}{l}\text { Asian } \\
\mathrm{n}=16\end{array}$ & $\begin{array}{l}\text { Latina } \\
\mathrm{n}=16\end{array}$ & $\begin{array}{c}\text { Middle } \\
\text { Eastern } \\
\mathbf{n}=\mathbf{3}\end{array}$ & $\begin{array}{c}\text { Native } \\
\text { American } \\
\mathbf{n}=\mathbf{2}\end{array}$ & $\begin{array}{l}\text { Percentage of } \\
\text { WOC }\end{array}$ \\
\hline $\begin{array}{l}\text { Supportive } \\
\text { Family and } \\
\text { Friends }\end{array}$ & $* 12$ & 7 & 6 & $* 3$ & 0 & $* 50 \%$ \\
\hline $\begin{array}{l}\text { Support } \\
\text { from Outside } \\
\text { Professional } \\
\text { Networks/ } \\
\text { Professional } \\
\text { Peers } \\
\end{array}$ & $* 17$ & 7 & $* 10$ & 1 & $* 2$ & $* 66 \%$ \\
\hline $\begin{array}{l}\text { Supportive } \\
\text { Virtual Spaces } \\
\end{array}$ & 2 & 0 & 0 & 0 & 0 & 4 \\
\hline $\begin{array}{l}\text { Physical } \\
\text { Fitness as a } \\
\text { Support }\end{array}$ & 2 & 0 & 2 & 0 & 0 & 7 \\
\hline $\begin{array}{l}\text { Spirituality/ } \\
\text { Faith-Based } \\
\text { Support }\end{array}$ & $* 10$ & 0 & 1 & 0 & 0 & 14 \\
\hline
\end{tabular}

*Placed within each subgroup of WOC. $50 \%$ or more of the women described this type of support.

I don't really think that I can identify one particular mentor, but I do feel that some of the professors here. ... I would go to this professor and ask them how their experience was. So, I feel that they are my mentors. ... For research, I will identify these professors. For teaching, I will identify those professors. So, I was, without thinking about it, probably looking for some mentors in the different areas.

In this example, Dr. Minerva was able to draw on various strengths from her colleagues and described them as mentors from whom she continually learns, even as a full professor.

Overall, the WOC described supportive colleagues as being willing and able to assist them in their research and teaching efforts. In addition to being supported, there was also a specific focus on assisting the women with developing their research agendas. Dr. Phoebe, an Asian assistant professor in mechanical engineering, explained that a senior female faculty member took an interest in mentoring her to help her develop research projects. She elaborated, "In the department there was a female faculty, she's also 20 years older. She just naturally served as a mentor. ... I can see she is trying to help me. ... I think she was also unconsciously telling me to do things that were more suitable for me, like project-wise. ... She helped me to establish my current project." Dr. Phoebe described an informal mentoring network within her department where a senior faculty 
member assisted her in developing her own research project, which is vital for tenuretrack faculty members.

The women described the impact of senior faculty mentorship within their departments for successful tenure. This is a crucial component for their career trajectories on the tenure track. Dr. Kaleen, a Black full professor in a public research university, was grateful to have two colleagues aid her during the initial years of her faculty career. She recalled:

I've been very blessed from I guess the time I started. Two faculty in my department, one, a White female and one, a White male, kind of took me on to mentor me my first few years. The White female, she met with me regularly to help coach me through the first papers, the first proposals, all the different kinds of things. And then really throughout she's been a resource when I was trying to make decisions of opportunities to engage in or not.

Reflecting on when she was an assistant professor in engineering, she found this vital to her current success as a full professor. She went on to describe how a male faculty member accelerated her timeline for establishing her own laboratory. When he transitioned into an administrative role, he strategically transferred his previous lab to her based on her research alignment with his.

These collegial environments described by the women were welcoming, inclusive, and supportive toward their growth and development as faculty. Colleagues voluntarily served as mentors, helped new faculty members navigate the norms of academia with specificity within their institution, shared teaching experiences, and offered advice for publishing, all of which helped the WOC succeed and commit to their academic careers. When these attributes were not present within a department, dramatically negative impacts on the experiences of WOC could result. This finding echoed Tinto's theory of student integration but at a faculty level, where the social system of the institution (peer groups and support system) and individual social integration were important in predicting whether they would persist (Tinto, 1975).

\subsubsection{Support from Outside Professional Networks and Organizations}

Sixty-six percent of the women described professional organizations and peer networks outside of their institutions as impactful for persisting as engineering faculty members. They were involved in different minority-serving organizations and communities. Some mentioned were the Alliance for Graduate Education and the Professoriate program, Computing Alliance for Hispanic-Serving Institutions, the College of Engineering of Puerto Rico, the American Physical Society, American Society of Civil Engineers, the Women in Engineering Leadership Institute, and the Institution for Women in Science. These organizations enhanced networks among underrepresented engineers of color. Dr. Therese, a Black associate professor in mechanical engineering, explained that these external organizations acted as "booster shots" that presented her with the opportunity 
to work with other faculty of color who were outside of her institution. She stated, "You have entities like [American Society for Engineering Education] where you can go and get what I call booster shots, and those booster shots are my way of maintaining that energy to keep moving for another six months to a year." Dr. Therese received inspiration from other faculty of color, which enabled her to overcome a harsh and unsupportive institutional environment. She continued:

Whenever I come back into my reality because my reality is not that [of the conference], my reality is to figure it out, sink or swim. Everyone's pushing to be this ... pushing for the top or towards the top and you're just trying to figure out your way to the top, with or without the same level of support. Because support comes in different packages, and it's multifaceted.

Dr. Therese is representative of the women who did not find supportive colleagues within their institutions. These women drew on external noninstitutional professional organizations, instead of support within their institutions, to find support to navigate within their current institutions.

Dr. Iris, a Latina associate professor in chemical and environmental engineering, elaborated on the type of support received from professional organizations and networks when she reflected on her experience at the Institution for Women in Science. Despite this organization being for women in science, as an engineer she found the camaraderie and mentoring to be helpful and crucial to her success. Dr. Iris began:

When I went up for tenure, most of them looked at me and said, 'Send us your resume a year before, we're gonna go through it, we want to help you, we want to get you going and succeed.' So I formed a very close bond with a lot of the women in science because they're more applicative for women and incredibly active with research.

Dr. Iris developed a strong relationship with other female scientists, who strategically served as informal mentors to support her as an engineering faculty member. She went on to describe her experience of being able to reach out to these women when she experienced "unfair" treatment. They would help support her through these difficult and toxic situations. Dr. Iris attributed much of her success on the tenure track and her mental well-being to the women from the Institution for Women in Science who supported her. Dr. Sierra (Black woman, administrator, industrial engineering) added national conferences among places for WOC to come together in comradery and support each other informally, as well as to have dinner together. She mentioned there was a need to attend conferences, some that were specific to WOC and others that were specific to technical knowledge for engineers to interact with a diverse network of WOC in engineering, since not every woman would attend the same conferences.

Volume 27, Issue 1, 2021 
In addition, WOC described staying in contact with their graduate school peers and advisors as an important source of support. Dr. Daphne, an Asian woman, full professor in an integrated engineering department, stayed in contact with her graduate school peers who were faculty members and identified them as her main resource of noninstitutional support. Dr. Daphne commented:

My graduate cohort has been really helpful. ... We keep in touch and talk about how things are going, such as our first-year teaching and stuff. [Those] who are doing the same things that I am doing understand what I'm going through. They [the graduate peer group] who are also developing new curricula. We will kind of talk about that professionally, of what hurdles we're seeing and what obstacles we need to overcome.

These peer groups provided a diverse range of support from personal to professional, and many established long-lasting friendships that fostered their success as engineering faculty members. There is a need for WOC to form these relationships within their doctoral programs since they can influence their experience on the tenure track. However, if their programs are unwelcoming and exclusive to WOC, it can present challenges in building peer groups.

Many of the WOC described staying in touch with their doctoral or postdoctoral advisors as a primary form of support. These trusted advisors assisted the women on various issues during different stages of their careers, for example, when they started new positions, advice on teaching practices, guidance on research, and work-life balance. Dr. Janelle, an Asian assistant professor in electronic engineering, identified her $\mathrm{PhD}$ advisor as the most important resource of support in academia. Her advisor provided tremendous support for her career development and was "the biggest influence" on her persisting on the tenure track as a junior faculty. He has continued to advise her, has "always been supportive," and even continued to review her proposals to ensure her success.

While the women would prefer to have supportive networks inside and outside of their institutions to provide a balanced and well-rounded network of support, this was not always the case. WOC, when institutional support was not present, relied heavily on professional organizations and networks to aid in their persistence. These findings have added to our knowledge of the support system for STEM success in general, since most studies on STEM persistence were at the undergraduate level where external support, such as existing professional networks outside their institution, was limited and rarely examined by researchers (Thiry, 2019). Many professional connections were fostered along the way as the women continued their exchanges with their previous advisors and were introduced to helpful organizations during their academic careers. Those mentors and organizations have guided them or empowered them to persist in an environment that marginalized and minoritized WOC. 


\subsection{Race-Specific Factors That are Important to Persistence for WOC Subgroups}

\subsubsection{Black Women: The Role of Spirituality and Faith-Based Support}

Fifty-three percent (10 out of 19) of the Black women described the influence of spiritual faith on their academic success. No other subgroup demonstrated this strong relationship between faith and spiritually as integral to their success. These Black women found purpose and discernment within their current positions and situations. For example, Dr. Jordan (Black woman, full professor of industrial and systems engineering) stated, "I'm a Christian ... God is my foundation. How I have survived, in graduate school I had this cohort, we went to church together, we did all kind of crazy stuff. We would be getting up, driving to early morning prayer at 6 AM. It was like the release." Dr. Jordan reflected on how she "survived" graduate school, an environment that she perceived to be toxic and unwelcoming. In another example, Dr. Tessa (Black woman, assistant professor of mechanical engineering) described the support of her spiritual community, despite not being academics; it provided her with support to "vent" and seek prayer when she felt it was needed:

I have a network of church community members that are sort of a mentor, they're like pastors. ... My faith-based community has been a huge help. ... I have a group of women I pray with, and we're connected on a particular app. I can just vent. I can say the raw stuff. They'll just be like, 'Okay, well, we're going to be praying for that. We'll pray.' They prayed me through tenure. They prayed through my NSF CAREER grant. They're not academics, but they understand these things are important and they'll be praying me through a lot of things that I wouldn't necessarily go to a mentor to say, 'Can you pray?'I mean, I'll go to them for practical advice, like, 'Okay, what do you think about this? What do you think about that?' But they can get the raw stuff. They get the raw vents, like, 'Man, can you believe this happened?'That I wouldn't necessarily want to share with professionals in my field. That's what's been great about them. They can get the raw stuff.

Dr. Tessa expressed the frustration of not being able to share in an academic setting the urge to pray that many of the Black women found imperative to their allaround well-being and continued success. These Black women who embraced spiritual support shared the experience that prayer helped maintain communication with other Black women, and they found relief in connecting with a group of peers who not only cared about their academic excellence but were attentive to their personal well-being as well. This unique group of Black women prayed for the participants' success, which enabled persistence because of their faith-driven practices and ideologies.

Volume 27, Issue 1, 2021 


\subsubsection{Latinas' Strong Affinity Toward Ethnic-Based Professional Organizations}

There were 16 Latina women in the project, and $65 \%$ of Latinas described support from outside professional networks, such as the Society of Women in Engineering, Louis Stokes Alliances for Minority Participation, Society of Hispanic Professional Engineers, and Institution of Women in Science.

Dr. Ariana (Latina, full professor of civil and structural engineering) attributed her involvement with the college of engineers of Puerto Rico in establishing collaborations and having a "supportive network to reach out to" to help navigate her tenure and promotion. Dr. Noelle reiterated her involvement in the Computing Alliance for HispanicServing Institutions as

the most influential group that has helped me keep in what I'm doing. I joined them early in my career, and they have been my mentors, my motivators, the people who really have helped me grow in my field. ... All the people from the [Computing Alliance for Hispanic-Serving Institutions] have been instrumental in helping me stay and guiding me.

Dr. Lola (Latina, full professor of civil engineering) reported on her involvement in professional organizations, "So I've really been in organizations like that professional, because you can do more with others, instead of alone."

In highlighting qualitative nuances, among Latinas there has been a trend similar to the Black women who have participated in race-ethnic specific organizations (89\%). These women participated in creating racially affirming spaces within national conferences with same-race groupings.

\subsubsection{Lack of Engineering Affinity Groups for Asian Women}

Dr. Susan (Asian woman) felt that Latinos and Black students throughout the pipeline had specific programming to increase their participation in engineering and create racial affinity spaces in STEM. As a Chinese American, she sensed:

[in] high school I was kind of left wondering. ... I feel like I've been a minority my whole life because again I really didn't fit in here and also I didn't fit in in China either, 'cause they knew I was American so that was kind of discouraging in that sense. I think there's more open opportunities and then also on campus for undergrads, there's SHPE and NESBE, respectively, for Hispanic students and African American students and there isn't an equivalent for Asian students for the equivalent for an engineering society. I'm not sure if we need it, but it's just ... there are disparities here and there. And there's a lot of scholarships and things associated with NSBE and SHPE that I would not be eligible for. 
Dr. Susan's positioning as an American-born-Chinese woman provided insight about her feelings of being excluded from race-based STEM programming and organizations. She observed the strong affinity and support that Latina and Black women engineering faculty members experience within race-based STEM programming and organizations. She commented that being a Chinese-born faculty member had affected her experience and relationships within the international faculty. Since her experience drew on growing up in the United States and visiting China, she did not feel she inherently belonged in either place. She was left wondering if Asian American students needed such support. Without this intersectional analysis, the exclusion of Asian women and the importance of race-specific networking spaces could be lost.

\subsubsection{Asian Women and Supportive Leadership and Colleagues}

Sixteen Asian women were included in the project, and they overwhelmingly, 11 out of $16(69 \%)$, described a positive impact from the support of leaders (e.g., department chairs, deans, and other administrators). The Asian women most desired support from leadership. Sixty-three percent of the Asian women, 10 out of 16, valued supportive faculty and colleagues within their institution. Asian women drew more strongly on people within their institutions for support. Dr. Yolanda, an (Asian assistant professor in civil engineering), depicted the situation at her institution:

My department head is very helpful. He is very open minded, and he's fair, and he is in an advisory role for the faculty members. I have a great deal of respect for him. I think my department head is a great resource and advisor or an advocate for me and other young faculty members. And the dean of my college, he's very supportive of female faculty members. ... I think he's a great advocate for the women faculty. His support from providing these internal funding opportunities of course not just for women faculty but for all the young faculty members in the department, in the grant programs that support this collaboration across departments.

Dr. Yolanda shared the various ways in which she found her department head and dean to support the growth and development of women engineering faculty. Beyond funding, she found them to be nice and welcoming toward her and other women. She felt the dean made attempts to focus on supporting women faculty members, which she appreciated. Dr. Susan (Asian assistant professor of industrial engineering) expressed her department chair's "vital role" in her success and persistence as an engineering faculty member. Asian women faculty in their interviews expressed an appreciation for a university or department that allotted them a comfortable amount of financial support for their research, conferences, and training. For example, Dr. Jocelyn, (Middle Eastern woman, associate professor of software engineering) stated:

Well, the support in my department, my school, is tremendous. Everybody is supportive in terms of allowing me to choose my schedules for classes, giving

Volume 27, Issue 1, 2021 
me the flexibility to choose where I publish, and giving me the financial support to attend conferences and pursue my research work as well. The university in general has a very strong drive to increase the research efforts, and that's also giving us a lot of support.

Dr. Jocelyn was representative of how the women had positive feelings toward departments in which they felt supported. Notably, the Asian women, unlike the Black, Latina, and Native American women, appear to have strong support from departmental and institutional leaders.

\section{DISCUSSION}

Colleagues and leadership within departments and institutions were the primary sources of support that enabled WOC to persist as engineering faculty members. When institutions could not provide sufficient support, WOCs actively sought help from outside professional communities and networks. They fostered long-lasting relationships with their advisors and peer groups in their doctoral programs, and their support as academic insiders influenced WOC success. Other professional communities also served as a source of support for WOC. They encountered underrepresented faculty who shared similar situations and received inspiration from each other's experience overcoming hardship. Opportunities for cooperation among WOC also emerged through networks, which helped them gain tenure. We argue that there is direct correlation between support leading to persistence in their faculty role. WOC directly and specifically related their decision to persist in their faculty positions or even take on an administrative role at their institutions because of the support they had and continued to receive. This makes sense because asking faculty to persist and not offering different types of support in that process creates an oppressive environment (McGee, 2020). Their racialized and gendered form of support mostly came from external environments; thus institutions could design support that recognizes the raced and gendered challenges that WOC endure in the workplace. We find that much of the support adopts a colorblind and genderblind perspective and thus minimizes the multiple forms of marginalization they face.

Given the emphasis that universities place on persistence in higher education, our study is particularly significant as it has uncovered assets within and outside of the current institutional structures that aid in the retention and success of WOC engineering faculty. All the women reported they were confident they would remain at their current institution the following year, meaning this group of women were not "at risk" of leaving the academy. These findings have the potential to support incoming WOC engineering faculty and deepen our understanding of the retention and success of WOC.

We have recommendations for engineering deans and other university leadership focused on engineering. Deans must realize that although WOC may be recruited to their campuses, the campuses of primarily White institutions do not offer environments that naturally or inherently support WOC. Women of color should not be blamed for this lack of existing support, however. Since mentoring support does not exist in most engi- 
neering departments and may be found more effectively among faculty and colleagues in professional societies and in external networks, providing funds to support faculty outside their work environments is needed, as well as thoughtful mentoring mapping to engineering faculty who are collegial, willing to learn about the intersectional experiences and challenges of WOC, and do not treat their protégés as threats or competition. Additionally, on-campus mentors should be assigned to WOC who are sensitive to the needs of WOC, see them as valuable, professional contributors to a unit, and grant them safety as they question and challenge environmental norms that hinder their success. Colleagues who contribute to the retention of WOC faculty should be acknowledged publicly and should serve as exemplars for others seeking effective strategies for mentoring and engaging WOC faculty. Deans should also mandate protocols for conducting successful searches, remembering that thoughtful, targeted outreach beyond advertising will be essential for efforts to recruit WOC. And for retention of WOC, specific efforts to improve institutional climates should include honest and systematic assessments of the current climate and environmental barriers.

The persistence of WOC in the engineering fields is a relatively understudied area, and this article provides rich information that not only details the resources of support within and outside institutions but also offers insights into what WOC can leverage to enable them to persist. Understanding and nurturing the resources of support for WOC has the potential to improve the engineering environment for WOC faculty and likely WOC students. A network of support is vital for WOC's persistence in academia. From institutional and noninstitutional support, many options are available for supporting the diversity of WOC networks that aid their navigation of the engineering field. Within their institutions, welcoming environments with supportive colleagues were major factors in cultivating inclusive communities for the women. However, when institutions did not provide sufficient support, WOC actively sought other avenues from professional communities and networks.

Intersectional analysis reveals that faculty draw on different resources of support across racial groups. Black women draw on spiritual and faith-based support, which is unique to their subgroup, demonstrating the importance of intersectional support aligned with the specific needs of groups. Because institutions do not readily have spiritual and faith-based approaches, these are all noninstitutional supports. The role of spirituality has proven to be crucial for Black women to persist in academia. There are many motivations for calling upon spirituality, such as empowerment (Smith, 2008), coping, inner peace (Bacchus and Holley, 2004), and resistance (Agosto and Karanxha, 2011). In this study, spirituality guided our participants to navigate institutional norms, create a peaceful space for research, and overcome challenges brought about by the STEM environment. More than academic success, WOC secure support from spiritual communities to maintain overall well-being. However, Dr. Tessa expressed the frustration of not being able to share the urge to pray in an academic setting. Many Black women faculty share a similar experience of working in an environment which is despiritual or antispiritual (Shahid, 2014). Surviving in a racist environment that provides little support for their spirituality is a difficult challenge in their academic development. Strategies for creating a more inclusive environment for Black women should stem from valuing their sources 
of power when implementing race-based policies. The integration of African American spirituality and the persistence of Black women can help to foster academic culture and create a system of support that advocates for diversity and equity.

Latinas describe the importance of race-based professional networking communities. However, even in these spaces the intersectional needs of Latinas can be lost on their White- and Asian-male-normed engineering environments. Although all the female faculty experience the difficulties of family-work balance, Asian and Latina female faculty are more impacted by cultural values that require them to adhere to traditional gender roles and family obligations (Sambamurthy et al., 2016; Sanchez-Peña et al., 2016). Flexible family and caretaker policies allow WOC to fulfill their responsibilities beyond their role as faculty members. Other than implementing gender-based policies, the support and understanding of family, in particular the spouse who is free from traditional expectations of gender roles, is vital to WOCs' academic development.

Compared with Black and Latina women faculty, Asian women tend to draw more on people within their institutions for support in conducting research, teaching classes, and pursuing tenure. In interviews, they expressed an appreciation for a university or department that advocated for them by providing a welcoming and enjoyable working environment. Unlike other racial groups, many Asian women faculty address the challenges of occupying the in-between space of two cultures and not feeling completely a part of either (Lin, 2006). This may explain why Asian women tend to rely heavily on institutional support that allows them to actively navigate academia. However, limited outside support creates a vulnerable situation for them if their working environment is toxic (Espinosa, 2011). This raises the question of how universities can provide institutional support for Asian women in the academy. Many of our participants had a greater affinity for university leadership and women faculty mentors who understand and share a similar experience. Therefore, Asian women are more likely to benefit from mentoring programs designed for minoritized women with administrative support.

Asian women faculty significantly rely on supportive administrative leadership and colleagues but less on support outside the institution. Unlike other racial groups, administrative leadership is the primary resource for Asian women to persist in academia, and it appears to allow them to enjoy working and become more devoted to research. Asian women overwhelmingly are employed by public or private research institutions, whereas Black and Latina women have greater institutional variety, including minorityserving institutions (MSIs). We wonder if the institutional and leadership support Asian women described was related to institutions that provide greater departmental and institutional support due to more resources than what is found at MSIs.

Finally, our findings illustrate that the noninstitutional sources of support appear to be at least as significant a factor in the retention and success of WOC engineering as institutional sources of support. Programmatic changes that seek to foster supportive environments within departments and institutions need to consider the challenges that WOC continue to face in the academy. We believe that improving the quality of mentoring that focuses on WOC faculty and providing spiritual sources of support (e.g., offering well-being classes on site, sponsoring an on-campus religious STEM organization, 
workshops on meditation and mindfulness) may be particularly crucial for bolstering resilience and persistence among WOC.

\section{CONCLUSION}

In this qualitative study, we investigated the experience of WOC in engineering faculty positions using persistence and intersectionality theory to understand how WOC persist in engineering academic careers. Both the internal factor of having supportive colleagues and the external sources of support from outside organizations were reported as important factors that help WOC engineer faculties thrive in their academic careers. There are also race-specific significant sources of support for each racial group - spiritual support for Black women, ethnic-based organizations for Latinx women, and institutional leadership for Asian women. This insight calls for more research on WOC in engineering and adopting an intersectional perspective that acknowledges the different racialized experiences among women of various racial backgrounds. Our research fills a gap in the existing literature where WOC in engineering academic appointments are rarely studied. We offer a glimpse into the variability in the experiences of WOC in engineering and the importance of applying the intersectional perspective in such studies. More importantly, we seek to inform both institutions and external organizations on the importance of support for WOC faculty and urge quality improvements in mentoring programs and the implementation of various supportive activities.

\section{ACKNOWLEDGMENT}

We would like to acknowledge Dr. Meseret F. Hailu and Kyung Hee Lee, who assisted with the interviews and analysis.

\section{REFERENCES}

Agosto, V., \& Karanxha, Z. (2011). Resistance meets spirituality in academia: "I prayed on it!". Negro Educational Review, 62(1-4), 41.

Aguirre Jr., A. (2000). Women and minority faculty in the academic workplace: Recruitment, retention, and academic culture. ASHE-ERIC Higher Education Report, Volume 27, Number 6. Jossey-Bass Higher and Adult Education Series. San Francisco, CA: Jossey-Bass.

Aldridge, J. L., Yoon, S. Y., Cox, M. F., Main, J. B., \& McGee, E. O. (2019). Development of the persistence of engineers in the academy survey (PEAS). Proceedings of the 126th American Society for Engineering Education (ASEE) Annual Conference and Exposition, Tampa, FL, USA.

Aldridge, J. L., Yoon, S. Y., Cox, M. F., Main, J. B., \& McGee, E. O. (2020). Validation of the climate scale in the persistence of engineers in the academy survey (PEAS). Proceedings of the 127th American Society for Engineering Education (ASEE) Annual Virtual Conference, USA.

Ahmed, S. (2012). On being included: Racism and diversity in institutional life. Durham, NC: Duke University Press.

Armstrong, M. A., \& Jovanovic, J. (2015). Starting at the crossroads: Intersectional approaches to institutionally supporting underrepresented minority women STEM faculty. Journal of Women and Minorities in Science and Engineering, 21(2), 141-57.

Volume 27, Issue 1, 2021 
Astin, A. (1993). What matters in college: Four critical years revisited. San Francisco, CA: Jossey-Bass.

Bacchus, D. N. A., \& Holley, L. C. (2004). Spirituality as a coping resource: The experiences of professional Black women. Journal of Ethnic \& Cultural Diversity in Social Work: Innovation in Theory, Research \& Practice, 13(4), 65-84. DOI: 10.1300/J051v13n04_04.

Bean, J., \& Metzner, B. (1985). A conceptual model of nontraditional undergraduate student attrition. Review of Educational Research, 55(4), 485-540.

Braxton, J. M., Hirschy, A. S., \& McClendon, S. A. (2004). Understanding and reducing college student departure. ASHE-ERIC Higher Education Report, Vol. 30, No. 3. Washington, DC: School of Education and Human Development, The George Washington University.

Berry, C. A., Cox, M. F., \& Main, J. B. (2014). Women of Color Engineering Faculty: An examination of the experiences and the numbers. In ASEE Annual Conference, Indianapolis, IN. Retrieved from https:// peer.asee.org/23314.

Braun, V., \& Clarke, V. (2006). Using thematic analysis in psychology. Qualitative Research in Psychology, 3(2), 77-101.

Collins, P. H. (1993). Toward a new vision: Race, class, and gender as categories of analysis and connection. Race, Sex \& Class, 25-45.

Crenshaw, K. W. (1989). Demarginalizing the intersection of race and sex: A black feminist critique of antidiscrimination doctrine. University of Chicago Legal Forum, 1989, 139-68.

DeCuir-Gunby, J. T., Long-Mitchell, L. A., \& Grant, C. (2009). The emotionality of women professors of color in engineering: A critical race theory and critical race feminism perspective. In P. A. Schutz \& M. Zembylas (Eds.), Advances in teacher emotion research: The impact on teachers' lives (pp. 323-42). New York: Springer.

DeCuir-Gunby, J. T., \& Walker-DeVose, D. C. (2013). Expanding the counterstory: The potential for critical race mixed methods studies in education. In Handbook of critical race theory in education (pp. 268-279). Milton Park, Abingdon, Oxfordshire: Routledge.

DeJoie, C. M. (1977). The black woman in alienation in white academic. The Negro Educational Review, 28(1), 4.

Donaldson, J., \& Graham, S. (1999). A model of college outcomes for adults. Adult Education Quarterly, 50(1), 24-40.

Eastman, M. G., Miles, M. L., \& Yerrick, R. (2019). Exploring the White and male culture: Investigating individual perspectives of equity and privilege in engineering education. Journal of Engineering Education, 108(4), 459-80. DOI: 10.1002/jee.20290.

Espinosa, L. L. (2008). The academic self-concept of African American and Latina(o) men and women in STEM majors. Journal of Women and Minorities in Science and Engineering, 14, 40. DOI: 10.1615/ JWomenMinorScienEng.v14.i2.40.

Espinosa, L. L. (2011). Pipelines and pathways: Women of color in undergraduate STEM majors and the college experiences that contribute to persistence. Harvard Educational Review, 81(2), 209-41.

Fereday, J., \& Muir-Cochrane, E. (2006). Demonstrating rigor using thematic analysis: A hybrid approach of inductive and deductive coding and theme development. International Journal of Qualitative Methods, 5(1), 80-92.

Ginther, D. K., \& Kahn, S. (2012). Education and academic career outcomes for women of color in science and engineering. Paper presented at the Conference for the Committee on Women in Science, Engineering, and Medicine, Washington, DC.

Harding, S. (1989). Is there a feminist method? In N. Tuana (Ed.), Feminism and science (pp. 17-32). Bloomington, IN: Indiana University Press.

Harris-Perry, M. V. (2011). Sister citizen: Shame, stereotypes, and Black women in America. New Haven, CT: Yale University Press.

Jean-Marie, G., \& Brooks, J. S. (2011). Mentoring and supportive networks for women of color in Academe. In G. Jean-Marie \& B. Lloyd-Jones (Eds.), Women of color in higher education: Changing directions and new perspectives (pp. 91-108). Bingley, UK: Emerald Group Publishing. 
Johnson, L., Thomas, K. M., \& Brown, L. (2017). Women of color in the STEM academic workplace. In J. Ballenger, B. Polnick, \& B. Irby (Eds.), Research on women and education. Women of color in STEM: Navigating the workforce (pp. 39-56). Charlotte, NC: IAP Information Age Publishing.

Leyva, L. A. (2016). An intersectional analysis of Latin@ College Women's counter-stories in mathematics. Journal of Urban Mathematics Education, 9(2), 81-121.

Lin, J. (2006). Building bridges, working for a better world. In Li, G. \& Beckett, G. (Eds.), "Strangers" of the academy: Asian women scholars in higher education (pp. 289-306). Sterling, VA: Stylus.

Main, J. B., Tan, L., Cox, M. F., McGee, E. O., \& Katz, A. (2020). The correlation between undergraduate student diversity and the representation of women of color faculty in engineering. Journal of Engineering Education, 109(4),843-64.

Malcolm, S., Hall, P., \& Brown, J. (1976). The double bind: The price of being a minority woman in science. Washington, DC: American Association for the Advancement of Science.

Martin, D. B. (2009). Researching race in mathematics education. Teachers College Record, 111(2), 295-338.

McGee, E. O. (2016). Devalued Black and Latino racial identities: A by-product of STEM college culture? American Educational Research Journal, 53(6), 1626-62.

McGee, E. O. (2020). Interrogating structural racism in STEM higher education. Educational Researcher. DOI: $10.3102 / 0013189 X 20972718$.

McGee, E. O., Thakore, B. K., \& LaBlance, S. (2016). The burden of being "model": Racialized experiences of Asian STEM college students. Journal of Diversity in Higher Education, 10(3), 253-70. DOI: $10.1037 /$ dhe0000022.

McGee, E. O., \& Bentley, L. C. (2017). The troubled success of Black women in STEM. Cognition and Instruction, 35(4), 265-89. DOI: 10.1080/07370008.2017.1355211.

McGee, E. O., Brockman, A., \& Park, C., (2020). Beyond stagnate! The underrepresentation of Black scholars in STEM higher education. Explorations in Diversifying Engineering in Faculty Initiative, Nashville, TN. Retrieved from https://blackengineeringphd.org.

Metz, G. W. (2004). Challenge and changes to Tinto's persistence theory: A historical review. Journal of College Student Retention: Research, Theory \& Practice, 6(2), 191-207.

National Research Council. (1998). Female Engineering Faculty at US Institutions: A data profile. Washington, DC: National Academies Press.

Ong, M., Wright, C., Espinosa, L., \& Orfield, G. (2011). Inside the double bind: A synthesis of empirical research on undergraduate and graduate women of color in science, technology, engineering, and mathematics. Harvard Educational Review, 81(2), 172-209.

Ong, M., Smith, J. M., \& Ko, L. T. (2018). Counterspaces for women of color in STEM higher education: Marginal and central spaces for persistence and success. Journal of Research in Science Teaching, 55(2), 206-45.

Robinson, W. H., McGee, E. O., Bentley, L. C., Houston, S. L., \& Botchway, P. K. (2016). Addressing negative racial and gendered experiences that discourage academic careers in Engineering. Computing in Science Engineering, 18(2), 29-39. DOI: 10.1109/MCSE.2016.38.

Sallee, M., Ward, K., \& Wolf-Wendel, L. (2016). Can anyone have it all? Gendered views on parenting and academic careers. Innovative Higher Education, 41(3), 187-202.

Sambamurthy, N., Main, J. B., Sanchez-Peña, M., Cox, M. F., \& McGee, E. (2016). Asian-American women engineering faculty: A literature review using an intersectional framework of race, class, and gender. In 2016 IEEE Frontiers in Education Conference (FIE) (pp. 1-7).

Sanchez-Pena, M., Main, J. B., Sambamurthy, N., Cox, M. F., \& McGee, E. O. (2016). The factors affecting the persistence of Latina faculty: A literature review using the intersectionality of race, gender, and class. In 2016 IEEE Frontiers in Education Conference (FIE) (pp. 1-9.)

Shahid, K. T. (2014). Finding Eden: How Black women use spirituality to navigate academia (Doctoral dissertation). Miami University, Oxford, $\mathrm{OH}$.

Sinclair, S., Hardin, C. D., \& Lowery, B. S. (2006). Self-stereotyping in the context of multiple social identities. Journal of Personality and Social Psychology, 90(4), 529-42.

Volume 27, Issue 1, 2021 
Smith, Y. Y. (2008). Womanist theology: Empowering Black women through Christian education. Black Theology, 6(2), 200-220. DOI: 10.1558/blth2008v6i2.200.

Thiry, H. (2019). What enables persistence? In E. Seymour \& A.-B. Hunter (Eds.), Talking about leaving revisited: Persistence, relocation, and loss in undergraduate STEM education (pp. 399-436). New York: Springer International Publishing. DOI: 10.1007/978-3-030-25304-2_12.

Thomas, K. M., Johnson-Bailey, J., Phelps, R. E., Tran, N. M., \& Johnson, L. (2013). Moving from pet to threat: Narratives of professional Black women. In L. Comas-Diaz \& B. Green (Eds.). The psychological health of women of color: Intersections, challenges, and opportunities (pp. 275-286). Westport, CT: Praeger.

Tinto, V. (1993). Leaving college: Rethinking the causes and cures of student attrition. 2nd ed. Chicago, IL: University of Chicago Press.

Turner, C. S. V. (2002). Women of color in academe: Living with multiple marginality. The Journal of Higher Education, 73(1), 74-93.

Turner, C. S. V., \& González, J. C. (2011). Faculty women of color: The critical nexus of race and gender. Journal of Diversity in Higher Education, 4(4), 199.

Yoder, B. L. (2017). Engineering by the numbers. In American Society for Engineering Education. Retrieved from https://www.asee.org/documents/papers-and-publications/publications/college-profiles/2017Engineering-by-Numbers-Engineering-Statistics.pdf.

\section{APPENDIX A}

TABLE A1: Summary of participants' demographic information

\begin{tabular}{|c|c|c|c|c|c|}
\hline & Pseudonym & Race & $\begin{array}{l}\text { Rank of } \\
\text { Professor }\end{array}$ & Subdiscipline & Institution Type \\
\hline 1 & Rachel & Black & $\begin{array}{l}\text { Assistant } \\
\text { Professor }\end{array}$ & Biomedical & Public Research \\
\hline 2 & Tessa & Black & $\begin{array}{l}\text { Assistant } \\
\text { Professor }\end{array}$ & Mechanical & Public Research \\
\hline 3 & Caroline & Black & Full Professor & $\begin{array}{l}\text { Chemical and } \\
\text { Biomolecular }\end{array}$ & Public Research \\
\hline 4 & Michelle & Black & $\begin{array}{l}\text { Associate } \\
\text { Professor }\end{array}$ & Field & $\begin{array}{l}\text { Public Research, } \\
\text { HBCU }\end{array}$ \\
\hline 5 & Hannah & Asian & $\begin{array}{l}\text { Associate } \\
\text { Professor }\end{array}$ & Industrial & Public Research \\
\hline 6 & Gwendolyn & Asian & $\begin{array}{l}\text { Assistant } \\
\text { Professor }\end{array}$ & Biomedical & $\begin{array}{l}\text { Private } \\
\text { Research, } \\
\text { Roman Catholic }\end{array}$ \\
\hline 7 & Hazel & Asian & Full Professor & $\begin{array}{l}\text { Electrical and } \\
\text { Computer }\end{array}$ & Public Research \\
\hline 8 & Susan & Asian & $\begin{array}{l}\text { Assistant } \\
\text { Professor }\end{array}$ & Industrial & Public Research \\
\hline 9 & Ava & Black & Full Professor & $\begin{array}{l}\text { Electrical and } \\
\text { Computer }\end{array}$ & Public Research \\
\hline 10 & Melinda & $\begin{array}{l}\text { Mixed (Filipino } \\
\text { and White) }\end{array}$ & $\begin{array}{l}\text { Associate } \\
\text { Professor }\end{array}$ & $\begin{array}{l}\text { Mechanical and } \\
\text { Environmental }\end{array}$ & $\begin{array}{l}\text { Private, Liberal } \\
\text { Arts }\end{array}$ \\
\hline 11 & Bernice & Black & Admin only & Industrial & Public Research \\
\hline
\end{tabular}


TABLE A1: (continued)

\begin{tabular}{|c|c|c|c|c|c|}
\hline 12 & Jordan & Black & Full Professor & $\begin{array}{l}\text { Industrial and } \\
\text { Systems }\end{array}$ & Public Research \\
\hline 13 & Josie & White & Instructor & Software & Public \\
\hline 14 & Tiffany & Black & Full Professor & $\begin{array}{l}\text { Chemical and } \\
\text { Biochemical }\end{array}$ & Public Research \\
\hline 15 & Tori & Black & Full Professor & Chemical & Private, $\mathrm{HBCU}$ \\
\hline 16 & Lauren & Black & Admin Only & Industrial & Public, HBCU \\
\hline 17 & Sierra & Black & Admin Only & Industrial & Public Research \\
\hline 18 & Daphne & Asian & $\begin{array}{l}\text { Assistant } \\
\text { Professor }\end{array}$ & General & $\begin{array}{l}\text { Private } \\
\text { Research, } \\
\text { Roman Catholic }\end{array}$ \\
\hline 19 & Daisy & Black & $\begin{array}{l}\text { Assistant } \\
\text { Professor }\end{array}$ & $\begin{array}{l}\text { Computer } \\
\text { Information } \\
\text { Systems }\end{array}$ & Private \\
\hline 20 & Jasmine & Asian & $\begin{array}{l}\text { Associate } \\
\text { Professor }\end{array}$ & $\begin{array}{l}\text { Mechanical and } \\
\text { Aerospace }\end{array}$ & Public Research \\
\hline 21 & Sylvia & Asian & Instructor & Electrical & Public Research \\
\hline 22 & Holly & Asian & $\begin{array}{l}\text { Associate } \\
\text { Professor }\end{array}$ & Mechanical & $\begin{array}{l}\text { Private, United } \\
\text { Methodist } \\
\text { Church affiliated }\end{array}$ \\
\hline 23 & Jocelyn & White & $\begin{array}{l}\text { Associate } \\
\text { Professor }\end{array}$ & Software & Private \\
\hline 24 & Ophelia & Black & $\begin{array}{l}\text { Assistant } \\
\text { Professor }\end{array}$ & $\begin{array}{l}\text { Industrial and } \\
\text { Systems }\end{array}$ & $\begin{array}{l}\text { Private } \\
\text { Research, } \\
\text { Roman Catholic }\end{array}$ \\
\hline 25 & Samantha & Asian & $\begin{array}{l}\text { Assistant } \\
\text { Professor }\end{array}$ & Biomedical & $\begin{array}{l}\text { Private, Roman } \\
\text { Catholic }\end{array}$ \\
\hline 26 & Yolanda & Asian & $\begin{array}{l}\text { Assistant } \\
\text { Professor }\end{array}$ & Civil & Public, Research \\
\hline 27 & Madison & $\begin{array}{l}\text { Latina (White- } \\
\text { Latina/Mexican) }\end{array}$ & $\begin{array}{l}\text { Assistant } \\
\text { Professor }\end{array}$ & $\begin{array}{l}\text { Aerospace and } \\
\text { Mechanical }\end{array}$ & $\begin{array}{l}\text { Private, Roman } \\
\text { Catholic }\end{array}$ \\
\hline 28 & Tatiana & Black & $\begin{array}{l}\text { Associate } \\
\text { Professor }\end{array}$ & $\begin{array}{l}\text { Civil and } \\
\text { Structural }\end{array}$ & Public Research \\
\hline 29 & Raven & $\begin{array}{l}\text { Latina } \\
\text { (Multiracial) }\end{array}$ & Full Professor & $\begin{array}{l}\text { Material Science } \\
\text { and Engineering }\end{array}$ & Public Research \\
\hline 30 & Therese & Black & $\begin{array}{l}\text { Associate } \\
\text { Professor }\end{array}$ & Mechanical & Public Research \\
\hline 31 & Margot & Asian & Full Professor & $\begin{array}{l}\text { Mechanical } \\
\text { Engineering }\end{array}$ & Public Research \\
\hline 32 & Alana & Black & Full Professor & $\begin{array}{l}\text { Transportation } \\
\text { Systems } \\
\text { Engineering }\end{array}$ & Public Research \\
\hline
\end{tabular}

Volume 27, Issue 1, 2021 
TABLE A1: (continued)

\begin{tabular}{|c|c|c|c|c|c|}
\hline & Pseudonym & Race & $\begin{array}{l}\text { Rank of } \\
\text { Professor }\end{array}$ & Subdiscipline & Institution Type \\
\hline 33 & Morgan & $\begin{array}{l}\text { White (Middle } \\
\text { Eastern) }\end{array}$ & $\begin{array}{l}\text { Associate } \\
\text { Professor }\end{array}$ & $\begin{array}{l}\text { Electrical } \\
\text { Engineering }\end{array}$ & Public Research \\
\hline 34 & Priscilla & Asian American & $\begin{array}{l}\text { Assistant } \\
\text { Professor }\end{array}$ & $\begin{array}{l}\text { Material Science } \\
\text { and Engineering }\end{array}$ & Public Research \\
\hline 35 & Michaela & $\begin{array}{l}\text { Alaskan Native } \\
\text { (Unangax, Aleut) }\end{array}$ & $\begin{array}{l}\text { Assistant } \\
\text { Professor }\end{array}$ & Civil & Public Research \\
\hline 36 & Eleanor & $\begin{array}{l}\text { Hispanic/ } \\
\text { Multiracial }\end{array}$ & Full Professor & Civil & $\begin{array}{l}\text { Public Land- } \\
\text { Grant, Sea- } \\
\text { Grant, HSI }\end{array}$ \\
\hline 37 & Noelle & $\begin{array}{l}\text { Hispanic/ } \\
\text { Multiracial }\end{array}$ & Full Professor & Computer & $\begin{array}{l}\text { Public Land- } \\
\text { Grant, Sea- } \\
\text { Grant, HSI }\end{array}$ \\
\hline 38 & Ariana & $\begin{array}{l}\text { Hispanic/ } \\
\text { Multiracial }\end{array}$ & Full Professor & Civil/Structural & $\begin{array}{l}\text { Public Land- } \\
\text { Grant, Sea- } \\
\text { Grant, HSI }\end{array}$ \\
\hline 39 & Veronica & $\begin{array}{l}\text { Asian/Indian- } \\
\text { American }\end{array}$ & Full Professor & $\begin{array}{l}\text { Electrical and } \\
\text { Computer } \\
\text { Engineering }\end{array}$ & $\begin{array}{l}\text { Public Land- } \\
\text { Grant, Sea- } \\
\text { Grant, HSI }\end{array}$ \\
\hline 40 & Selah & Hispanic/Latina & Full Professor & Industrial & $\begin{array}{l}\text { Public Land- } \\
\text { Grant, Sea- } \\
\text { Grant, HSI }\end{array}$ \\
\hline 41 & Minerva & Hispanic/Latina & Full Professor & Industrial & $\begin{array}{l}\text { Public Land- } \\
\text { Grant, Sea- } \\
\text { Grant, HSI }\end{array}$ \\
\hline 42 & Ida & Hispanic/Latina & $\begin{array}{l}\text { Associate } \\
\text { Professor }\end{array}$ & Civil & $\begin{array}{l}\text { Public Land- } \\
\text { Grant, Sea- } \\
\text { Grant, HSI }\end{array}$ \\
\hline 43 & Lola & Hispanic/Latina & Full Professor & Civil & $\begin{array}{l}\text { Public Land- } \\
\text { Grant, Sea- } \\
\text { Grant, HSI }\end{array}$ \\
\hline 44 & Sydney & $\begin{array}{l}\text { Hispanic/ } \\
\text { Multiracial }\end{array}$ & $\begin{array}{l}\text { Associate } \\
\text { Professor }\end{array}$ & Mechanical & $\begin{array}{l}\text { Public Land- } \\
\text { Grant, Sea- } \\
\text { Grant, HSI }\end{array}$ \\
\hline 45 & Winnie & Hispanic/White & $\begin{array}{l}\text { Associate } \\
\text { Professor }\end{array}$ & Industrial & $\begin{array}{l}\text { Public Land- } \\
\text { Grant, Sea- } \\
\text { Grant, HSI }\end{array}$ \\
\hline 46 & Penny & Latina & $\begin{array}{l}\text { Assistant } \\
\text { Professor }\end{array}$ & $\begin{array}{l}\text { Weapons and } \\
\text { Systems }\end{array}$ & $\begin{array}{l}\text { Federal Service } \\
\text { Academy/Public }\end{array}$ \\
\hline 47 & Kaleen & Black & Full Professor & $\begin{array}{l}\text { Electrical and } \\
\text { Computer } \\
\text { Engineering }\end{array}$ & Public Research \\
\hline
\end{tabular}


TABLE A1: (continued)

\begin{tabular}{|c|c|c|c|c|c|}
\hline 48 & Annie & Native American & Instructor & $\begin{array}{l}\text { Pre-Engineering } \\
\text { (Bachelor's } \\
\text { ChemE, Master's } \\
\text { Enviro Science) }\end{array}$ & Tribal College \\
\hline 49 & Lucille & Latina & Full Professor & $\begin{array}{l}\text { Materials Science } \\
\text { and Engineering }\end{array}$ & Public, Research \\
\hline 50 & Janelle & Asian & $\begin{array}{l}\text { Assistant } \\
\text { Professor }\end{array}$ & $\begin{array}{l}\text { Electrical } \\
\text { Engineering }\end{array}$ & Public, Research \\
\hline 51 & Carrie & $\begin{array}{l}\text { Latina (non- } \\
\text { White) }\end{array}$ & $\begin{array}{l}\text { Associate } \\
\text { Professor }\end{array}$ & $\begin{array}{l}\text { Mechanical } \\
\text { Engineering }\end{array}$ & Public Research \\
\hline 52 & Debbie & Black & $\begin{array}{l}\text { Associate } \\
\text { Professor }\end{array}$ & $\begin{array}{l}\text { Mechanical } \\
\text { Engineering }\end{array}$ & Private Research \\
\hline 53 & Jayda & Black & $\begin{array}{l}\text { Assistant } \\
\text { Professor }\end{array}$ & $\begin{array}{l}\text { Biological and } \\
\text { Agricultural } \\
\text { Engineering }\end{array}$ & Public Research \\
\hline 54 & Mia & Latina & Full Professor & $\begin{array}{l}\text { Industrial and } \\
\text { Systems }\end{array}$ & Public Research \\
\hline 55 & Phoebe & Asian & $\begin{array}{l}\text { Assistant } \\
\text { Professor }\end{array}$ & $\begin{array}{l}\text { Mechanical } \\
\text { Engineering }\end{array}$ & $\begin{array}{l}\text { Public } \\
\text { Polytechnic } \\
\text { University }\end{array}$ \\
\hline 56 & Willow & $\begin{array}{l}\text { Asian } \\
\text { (Taiwanese) }\end{array}$ & Full Professor & $\begin{array}{l}\text { Chemical } \\
\text { and Materials } \\
\text { Engineering }\end{array}$ & $\begin{array}{l}\text { Public } \\
\text { Polytechnic } \\
\text { University }\end{array}$ \\
\hline 57 & Iris & Latina & Full Professor & $\begin{array}{l}\text { Chemical and } \\
\text { Environmental } \\
\text { Engineering }\end{array}$ & Public Research \\
\hline
\end{tabular}

\section{APPENDIX B. PERSISTENCE CODESIARCHITECTURE}

\section{Early Influences of Persistence in Engineering}

a. Early talent in math that was fostered by key stakeholders within education (e.g., math teachers, school administrators)

b. Enrollment and successful participation in advanced STEM coursework

c. An envisioning of a career in engineering

\section{Pathways to the Professoriate}

a. Varying ideologies of career choice (e.g., did not initially major in engineering to be a professor

b. Competing life demands (e.g., started a family, marriage, pursued industry employment initially) 
c. Opportunity knocked (e.g., started to teach one college course, scholarship to complete engineering $\mathrm{PhD}$ with a commitment to be a faculty member, programing for minoritized participation in engineering -LSAMP, SREB, Institute for Teaching and Mentoring, etc.)

d. Overcame barriers to securing the $\mathrm{PhD}$ (e.g., going back to school after working, starting a family, etc.)

\section{Supportive Department//nstitution}

a. Thriving in small departments (20 or less faculty members in one engineering department)

b. Thriving in departments that have a significant number of women faculty members (may be a relationship between certain disciplines that have significant populations of women - biomedical engineering)

c. Thriving through departmental/institutional mentorship

d. Embracing opportunities to help other minoritized students succeed (e.g., becoming the faculty program director for LSAMP and similar types of programs)

e. Advocating and receiving credit for service via course reductions, titles, and salary increases

f. The intrinsic passion/love of teaching (contributing to the next generation of engineering scholars)

g. Gender financial equity for salary and raises

h. Enjoys the flexibility of being a professor (e.g., can set your own hours)

i. Children benefit from university resources (e.g., summer internships, campusrelated daycare, school, college tuition offered, often on employment rates, etc.)

j. Spousal hire policy

\section{Future Trajectory as a Professor but with Even Greater Reach}

a. Do more with service and/or admin to impact engineering on an even more significant level

b. Aspirations toward tenure and promotion

c. Desire to serve/continue to serve as a female role model for recruiting or retaining women in STEM fields 